\title{
PROBABILITY MODAL TRANSFER TO THE FORWARDER AT TERMINAL LAMONG BAY SURABAYA
}

\author{
Rezki Setya Irsadi ${ }^{a}$ and Hera Widyastutib
}

\begin{abstract}
Currently the mobilization of freight transport from Surabaya to Jakarta or otherwise served by three types of modes transport, including truck, train, and marine vessels. But the majority of the freight transport cargo in the corridor SurabayaJakarta is served by trucking so that the impact on the capacity of roads and road load increases. The purpose of this study was to estimate the probability EMKL service manager / Forwarder to switch modes from container truck to railway mode container. The methods used to analyze the research data is a binary logistic regression. The results of these studies indicate that the travel time during the 3-day trip by truck containers will potentially probability modal transfer containers from trucks to rail containers reached $87.49 \%$, and the more need for the use of container sizes of $20 \mathrm{ft}$. at a cost of Rp. 2,500,000 will potentially modal transfer containers from trucks to rail container by $82.34 \%$, more than the container size of $40 \mathrm{ft}$. at a cost of Rp. 4,000,000 by $50 \%$.
\end{abstract}

Keywords: Probability, Transfer Mode, Trucks Container, Railway Container, Binary Logistic Regression.

\begin{abstract}
Abstrak: Saat ini mobilisasi muatan dari Surabaya menuju Jakarta ataupun sebaliknya dilayani oleh 3 jenis moda transportasi, meliputi truk, kereta api, dan kapal. Akan tetapi mayoritas pengangkutan muatan di koridor Surabaya dan Jakarta masih dilayani oleh angkutan truk saja sehingga berdampak pada kapasitas ruas jalan, dan beban jalan yang semakin meningkat. Tujuan penelitian ini adalah untuk memperkirakan probabilitas pengelola jasa EMKL/Forwarder untuk beralih moda dari truk petikemas ke moda kereta api petikemas. Metode yang digunakan untuk menganalisis data penelitian adalah regresi logistik biner. Hasil dari penelitian tersebut menunjukkan bahwa waktu tempuh selama 3 hari perjalanan menggunakan truk petikemas akan berpotensi terhadap probabilitas perpindahan moda dari truk petikemas ke kereta api petikemas mencapai 87,49 \%, dan semakin banyak kebutuhan penggunaan kontainer ukuran $20 \mathrm{ft}$. dengan biaya Rp. 2.500 .000 akan berpotensi terhadap perpindahan moda dari truk petikemas ke kereta api petikemas sebesar $82.34 \%$, lebih banyak jika dibandingkan dengan kontainer ukuran $40 \mathrm{ft}$. dengan biaya Rp. 4.000 .000 sebesar $50 \%$.
\end{abstract}

Kata Kunci: Probabilitas, Perpindahan Moda, Truk Petikemas, Kereta Api Petikemas, Regresi Logistik Biner.

\section{PENDAHULUAN}

Pengoperasian Terminal Teluk Lamong sejak tanggal 22 Mei 2015, diharapkan dapat menjadi alternatif bagi para pengusaha untuk melakukan pengiriman barang petikemas melalui Pelabuhan Teluk Lamong. Hal ini disebabkan karena volume aktivitas bongkar muat di kawasan Pelabuhan Tanjung Perak Surabaya mengalami kelebihan kapasitas, sehingga berdampak pada durasi waktu pengiriman barang dan kemacetan yang disebabkan oleh antrian truk petikemas di area Pelabuhan Tanjung Perak Surabaya. Terminal Teluk Lamong Surabaya memiliki peranan yang penting dalam melayani kegiatan bongkar muat petikemas domestik, petikemas internasional, dan curah kering dengan standar pangan. Peralatan bongkar muat yang tersedia di Terminal ini seperti Container yard stock pile, Container Crane, Shipun loader, Conveyor,Automatic Stocking crane, dan Headtruck hampir seluruhnya digerakkan secara semi otomatis,

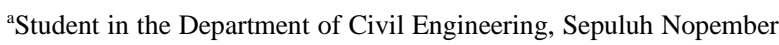
Institute of Technology (ITS), ITS Campus, Sukolilo, Surabaya 60111, Indonesia. Email: Rezki_setya@yahoo.com

${ }^{b}$ Lecturer in the Department of Civil Engineering, Sepuluh Nopember Institute of Technology (ITS), ITS Campus, Sukolilo, Surabaya 60111, Indonesia. Email: hera@ce.its.ac.id

Note. The manuscript for this paper was submitted for review and possible publication on January 05, 2017. This paper is part of the ITS Journal of Civil Engineering, Vol. 32, No. 1, May 2017. (C) ITS Journal of Civil Engineering, ISSN 2579-9029/2017. sehingga ditinjau dari aspek keselamatan, ketepatan, dan kecepatan waktu pelayanan dapat berpengaruh terhadap produktivas pelayanannya.

Pengelola jasa EMKL/Forwarder merupakan perusahaan yang berperan sebagai pengantara yang membantu pemilik barang untuk mengurus pengiriman maupun penerimaan barang dengan perusahaan pelayaran serta membantu mengurusi dokumen ekspor/impor. Perusahan EMKL/Forwarder juga mempunyai kewenenagan dalam memilih kendaraan yang akan digunakan dalam proses transportasi barang dari tempat asal ke tempat tujuan.

\section{METODOLOGI}

Penelitian ini dilaksanakan dengan menggunakan beberapa langkah - langkah yang sistematis. Langkah langkah tersebut dapat dilihat pada Gambar 1.

\section{Identifikasi Masalah}

Saat ini mobilisasi muatan dari Surabaya menuju Jakarta ataupun sebaliknya dilayani oleh 3 jenis moda transportasi. Meliputi truk, kereta api, dan kapal. Akan tetapi mayoritas pengangkutan muatan di koridor Surabaya dan Jakarta masih dilayani oleh angkutan truk. Sehingga berdampak pada kapasitas ruas jalan dan beban jalan menjadi semakin meningkat. Dari fakta tersebut muncul wacana untuk mengalihkan moda transportasi yang sebelumnya diangkut menggunakan truk dialihkan menggunakan jasa angkutan kereta api ataupun kapal laut. 


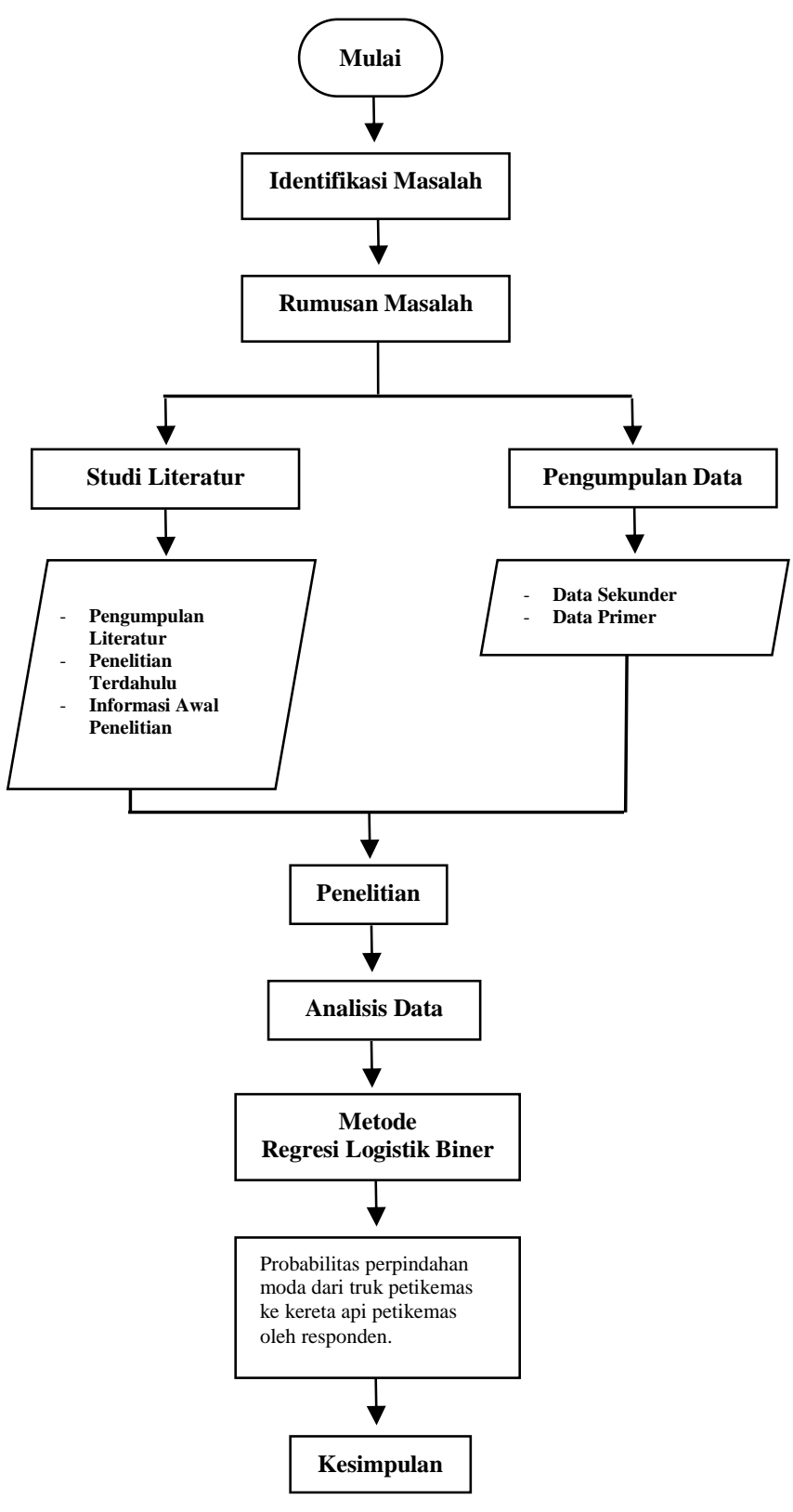

Gambar 1. Diagram Alur Penelitian

\section{Rumusan Masalah}

Berapa besar probabilitas pengelola jasa EMKL/Forwarder yang bersedia beralih moda dari truk petikemas ke kereta api petikemas di Terminal Teluk Lamong pada rute Surabaya - Jakarta.

\section{Studi Literatur}

Tujuan dari studi literatur ini adalah untuk mencari bahan rujukan atau informasi berupa, teori, rumus perhitungan, dan hasil penelitian terdahulu, yang nantinya akan digunakan sebagai acuan dalam penelitian ini.

\section{Pengumpulan Data}

Metode yang digunakan dalam pengumpulan data meliputi:

1. Data Sekunder
Data sekunder didapatkan dari studi literatur dan wawancara/interview kepada instansi yang terkait didalam penelitian ini. Antara lain:

a. PT. Terminal Teluk Lamong Surabaya

b. Perusahaan EMKL/Forwarder

c. PT. KAI DAOP 8 Surabaya dan PT. KA Logistik (Stasiun Kalimas)

Tujuan dari wawancara/interview ini adalah untuk mengetahui gambaran atau situasi dan kodisi aktivitas proses kegiatan bongkar muat, proses pendistribusian barang, dan biaya/tarif yang dialami oleh responden,

\section{Data Primer}

Berdasarkan data sekunder yang sudah terkumpul berupa informasi tekait dengan proses kegiatan bongkar muat, pengiriman petikemas, biaya/tarif bongkar muat, maka langkah berikutnya adalah menyusun form survei (kuesioner). Form survei (kuesioner) tersebut ditujukan kepada responden yaitu pengelola jasa EMKL/Forwarder.

Form survei (kuesioner) terdiri dari atribut - atribut yang berkaitan dengan aktivitas proses kegiatan bongkar muat barang, proses pendistribusian barang, dan biaya. Adapun masing - masing atribut tersebut adalah sebagai berikut:

a. Jenis Muatan Barang

b. Asal dan Muatan Barang

c. Moda Kendaraan

d. Jarak Tempuh

e. Waktu Tempuh

f. Frekuensi Perjalanan

g. Bentuk Pelayanan

h. Biaya

Tujuan dari pembuatan kuesioner ini adalah untuk mengetahui jawaban responden terhadap probabilitas kesediaannya beralih menggunakan moda dari truk petikemas ke kereta api petikemas di Terminal Teluk Lamong dengan rute Surabaya - Jakarta.

\section{Penelitian}

Penelitian ini dilakukan dengan cara menyebarkan form survei (kuesioner) ditempat Perusahaan Ekspedisi Muatan Kapal Laut (EMKL)/Forwarder yang tersebar di kota Surabaya.

Berdasarkan rincian daftar tersebut maka diambil lokasi penyebaran form kuesioner di Kota Surabaya. Di Kota Surabaya terdapat Perusahaan Forwader/EMKL yang paling terbanyak, dengan jumlah perusahaan 326. Maka jumlah tersebut dijadikan sebagai acuan untuk menentukan populasinya. Untuk menentukan sampel pada penelitian ini digunakan perhitungan sebagai berikut:

$$
n=\frac{N}{1+N(a)^{2}}
$$

Keterangan:

$$
\begin{array}{ll}
n & : \text { Jumlah Sampel } \\
N & : \text { Jumlah Populasi } \\
a & : 0.05 \text { (Tingkat kesalahan) }
\end{array}
$$$$
n=\frac{326}{1+326 x(0,05)^{2}}=179,6 \sim 180
$$ 
Tabel 1. Rincian Daftar Lokasi dan Jumlah Perusahaan Forwarder/EMKL

\begin{tabular}{|c|l|c|}
\hline No. & \multicolumn{1}{|c|}{ Lokasi } & $\begin{array}{c}\text { Jumlah } \\
\text { Perusahaan }\end{array}$ \\
\hline 1. & Surabaya & 326 \\
\hline 2. & Gresik & 5 \\
\hline 3. & Sidoarjo & 12 \\
\hline 4. & Pasuruan & 2 \\
\hline 5. & Jombang & 1 \\
\hline 6. & Jawa Tengah & 1 \\
\hline 7. & Jakarta & 13 \\
\hline 8. & Tangerang & 1 \\
\hline 9. & Bekasi & 1 \\
\hline 10. & Balikpapan & $\mathbf{3 6 4}$ \\
\hline & Total Jumlah Keseluruhan & \\
\hline
\end{tabular}

Sumber: Didapatkan penulis dari meringkas Customer List Pelabuhan Teluk Lamong, Tahun 2015.

Dengan demikian maka jumlah keseluruhan responden yang akan dijadikan objek penelitian atau yang akan mendapatkan form survei (kuesioner) sebanyak 180 pengelola jasa EMKL/Forwarder.

Karena pada kondisi saat ini masih belum dioperasikan jalur kereta api yang menghubungkan ke Terminal Teluk Lamong dan belum ada rute khusus untuk kereta api petikemas, maka akan dibuat asumsi tentang rute pelayanan Surabaya - Jakarta yang terhubung dari Stasiun Indro Gresik dengan Stasiun Pasoso Jakarta. Informasi ini dibuat berdasarkan rute kereta api petikemas tujuan Stasiun Kalimas Surabaya dengan Stasiun Pasoso Jakarta yang terdapat pada PT. Kereta Api Logistik (KALOG).

\section{ANALISIS DAN PEMBAHASAN}

Digunakan analisis regresi logistik biner untuk mengetahui jawaban pengisian form survei (kuesioner) terhadap data perpindahan moda dari truk petikemas ke kereta api petikemas oleh pengelola jasa EMKL/Forwarder. Pada pembentukan model regresi logistik biner langkah awal adalah menerapkan variabel bebas dan variabel terikat, kemdian langkah berikutnya menguji masing - masing variabel bebasnya terhadap variabel terikatnya untuk diketahui hasil yang berpengaruh secara signifikan terhadap variabel terikatnya.

1. Variabel Bebas (Independent Variable)

Variabel bebas pada penelitian ini terdapat pada susunan form survei (kuesioner) pada pertanyaan no. 1 sampai no.16, pertanyaan tersebut meliputi:

- Jenis muatan barang

- Asal barang

- Tujuan pengiriman barang

- Bentuk pelayanan

- Pelabuhan yang digunakan

- Kendaraan yang digunakan

- Alasan menggunakan truk petikemas

- Kendala saat menggunakan truk petikemas

- Frekuensi perjalanan pengiriman barang

- Jarak tempuh menuju pelabuhan
- Waktu tempuh menuju pelabuhan

- Kendaraan yang digunakan pada rute pengiriman barang (Surabaya - Jakarta)

- Rata - rata waktu perjalanan pengiriman barang pada rute (Surabaya - Jakarta)

- Frekuensi perjalanan pengiriman barang pada rute (Surabaya - Jakarta)

- Persetujuan terhadap biaya

- Pelayanan terhadap jadwal keberangkatan/kedatangan kereta api petikemas.

2. Variabel Terikat (Dependent Variable)

Variabel terikat pada penelitian ini terdapat pada susunan form survei (kuesioner) yang terakhir yaitu pada bagian yang berisi pertanyaan terkait dengan kesediaan berpindah moda dari truk petikemas menggunakan kereta api petikemas.

\section{Pengujian variabel}

Berdasarkan hasil pengujian variabel bebas (independent variable) terhadap variabel terikat (dependent variable), maka sudah dapat diketahui bahwa variabel bebas yang berpengaruh secara signifikan terhadap variabel terikatnya adalah variabel rata - rata waktu tempuh untuk rute tujuan Surabaya - Jakarta dan variabel persetujuan terhadap biaya kereta api petikemas rute tujuan Surabaya - Jakarta.

\section{Variabel rata - rata waktu tempuh rute tujuan Surabaya - Jakarta}

Berdasarkan Tabel 2 hasil perthitungan tersebut menunjukkan bahwa variabel rata - rata waktu tempuh perjalanan rute Surabaya - Jakarta berpengaruh signifikan terhadap variabel terikat karena nilai signifikannya sig. < $\alpha$. Dimana nilai $\alpha=0.05 \%$. Yaitu $0.010 \%<0.05 \%$.

\section{Waktu Tempuh (1)}

Persamaan dari pemodelan hasil uji masing masing variabel bebas tersebut adalah sebagai berikut: Logit $(\mathrm{p})=\ln \frac{p}{1-p}$

$$
=-1.946+2.862
$$

$=0.916$ Waktu Tempuh (1)

Maka peluang responden dengan waktu tempuh 2 hari setiap kali melakukan perjalanan untuk tetap menggunakan truk petikemas adalah sebesar:

$$
\begin{aligned}
P(2 \text { hari }) & =\frac{1}{1+e^{\text {logit }}} \\
P(2 \text { hari }) & =\frac{1}{1+2.718^{0.916}} \\
& =28.57 \%
\end{aligned}
$$

Sedangkan peluang responden dengan waktu tempuh 2 hari setiap kali melakukan perjalanan untuk berpindah moda dari moda truk petikemas ke moda kereta api petikemas adalah sebesar:

$$
\begin{aligned}
P(2 \text { hari }) & =\frac{e^{\text {logit }}}{1+e^{\text {logit }}} \\
P(2 \text { hari }) & =\frac{2.718^{0.916}}{1+2.718^{0.916}} \\
& =71.42 \%
\end{aligned}
$$

\section{Waktu Tempuh (2)}

Persamaan dari pemodelan hasil uji masing masing variabel bebas tersebut adalah sebagai berikut:

$$
\begin{aligned}
\operatorname{Logit}(\mathrm{p})= & \ln \frac{p}{1-p} \\
& =-1.946+3.892 \\
& =1.946 \text { Waktu Tempuh }(2)
\end{aligned}
$$


Tabel 2. Hasil Uji Regresi Logistik Biner Untuk Variabel Rata - rata Waktu Tempuh untuk Rute Tujuan Surabaya Jakarta

Variables in the Equation

\begin{tabular}{|c|c|c|c|c|c|c|c|}
\hline & & B & S.E. & Wald & $d f$ & Sig. & $\operatorname{Exp}(B)$ \\
\hline \multirow[t]{5}{*}{ Step $1^{a}$} & $\begin{array}{l}\text { Rata_rata_waktu_ } \\
\text { perjalanan_rute_- } \\
\text { Surabaya_Jakarta }\end{array}$ & & & 11.279 & 3 & .010 & \\
\hline & $\begin{array}{l}\text { Rata_rata_waktu_ } \\
\text { perjalanañ_rute_- } \\
\text { Surabaya_Jakarta(1) }\end{array}$ & 2.862 & 1.128 & 6.443 & 1 & .011 & 17.500 \\
\hline & $\begin{array}{l}\text { Rata_rata_waktu_ } \\
\text { perjaTanañ_rute_- } \\
\text { Surabaya_Jakarta(2) }\end{array}$ & 3.892 & 1.309 & 8.835 & 1 & .003 & 49.000 \\
\hline & $\begin{array}{l}\text { Rata_rata_waktu_ } \\
\text { perjalanañ_rute_- } \\
\text { Surabaya_Jakarta(3) }\end{array}$ & 2.234 & 1.075 & 4.320 & 1 & .038 & 9.333 \\
\hline & Constant & -1.946 & .756 & 6.626 & 1 & .010 & .143 \\
\hline
\end{tabular}

Tabel 3. Probabilitas Perpindahan Moda Truk Petikemas Ke Moda Kereta Api Petikemas Rute Tujuan Surabaya - Jakarta

\begin{tabular}{|l|c|c|}
\hline \multicolumn{2}{|c|}{ Waktu Tempuh } & Probabilitas \\
\hline 2 Hari & 0.916 & $71.42 \%$ \\
\hline 3 Hari & 1.946 & $87.49 \%$ \\
\hline$>3$ Hari & 0.288 & $57.14 \%$ \\
\hline
\end{tabular}

Maka peluang responden dengan waktu tempuh 3 hari setiap kali melakukan perjalanan untuk tetap menggunakan truk petikemas adalah sebesar:

$$
\begin{aligned}
P(3 \text { hari }) & =\frac{1}{1+e^{-\log i t}} \\
P(3 \text { hari }) & =\frac{1}{1+2.718^{1.946}} \\
& =12.50 \%
\end{aligned}
$$

Sedangkan peluang responden dengan waktu tempuh 3 hari setiap kali melakukan perjalanan untuk berpindah moda dari moda truk petikemas ke moda kereta api petikemas adalah sebesar:

$$
\begin{aligned}
P(3 \text { hari }) & =\frac{e^{\text {logit }}}{1+e^{\log i t}} \\
P(3 \text { hari }) & =\frac{2.718^{1.946}}{1+2.718^{1.946}} \\
& =87.49 \%
\end{aligned}
$$

\section{Waktu Tempuh (3)}

Persamaan dari pemodelan hasil uji masing masing variabel bebas tersebut adalah sebagai berikut:

$$
\begin{aligned}
\operatorname{Logit}(\mathrm{p})= & \ln \frac{p}{1-p} \\
& =-1.946+2.234 \\
& =0.288 \text { Waktu Tempuh (3) }
\end{aligned}
$$

Maka peluang responden dengan waktu tempuh $>3$ hari setiap kali melakukan perjalanan untuk tetap menggunakan truk petikemas adalah sebesar:

$$
\begin{aligned}
P(>3 \text { hari }) & =\frac{1}{1+e^{\log i t}} \\
P(>3 \text { har } i) & =\frac{1}{1+2.718^{0.288}} \\
& =42.85 \%
\end{aligned}
$$

Sedangkan peluang responden dengan waktu tempuh $>3$ hari setiap kali melakukan perjalanan untuk berpindah moda dari moda truk petikemas ke moda kereta api petikemas adalah sebesar:

$$
P(>3 \text { hari })=\frac{e^{\text {logit }}}{1+e^{\text {logit }}}
$$

$$
\begin{aligned}
P(>3 \text { hari }) & =\frac{2.718^{0.288}}{1+2.718^{0.288}} \\
& =57.14 \%
\end{aligned}
$$

Ringkasan probabilitas perpindahan moda dari moda truk petikemas ke moda kereta api petikemas untuk variabel waktu tempuh rata - rata rute tujuan Surabaya - Jakarta dapat dilihat pada Tabel 3.

Tabel 2 menunjukkan bahwa dalam waktu tempuh selama 3 hari perjalanan menggunakan truk petikemas, maka semakin berpotensi Probabilitas perpindahan moda pada waktu tempuh $>3$ hari menunjukkan angka yang sangat kecil. Hal ini disebabkan karena faktor rata - rata perjalanan rute tujuan Surabaya - Jakarta bila ditempuh dengan moda truk petikemas secara umum ditempuh dalam waktu 3 hari.

Probabilitas perpindahan moda dari truk petikemas ke moda kereta api petikemas, dengan probabilitas perpindahan mencapai $87.49 \%$.

\section{Pengujian Model Regresi Logistik}

Sebelum model dinyatakan layak, model tersebut harus diuji statistik. Pengujian model regresi logistik biner menggunakan uji Hosmer and Lemeshow Test, dengan asumsi:

$\mathrm{H}_{0}$ : Model telah cukup mampu menjelaskan data/sesuai

$\mathrm{H}_{1} \quad$ : Model tidak cukup mampu menjelaskan data Tolak $\mathrm{H}_{0}$ jika sig. $<0.05$

Tabel 4. Hosmer and Lemeshow Test Untuk Variabel Waktu Tempuh Rata - rata Rute Tujuan (Surabaya Jakarta)

Hosmer and Lemeshow Test

\begin{tabular}{|l|r|r|c|}
\hline Sten & Chi-square & df & Sig. \\
\hline 1 & .000 & 2 & 1.000 \\
\hline
\end{tabular}


Terlihat dari Tabel 4 bahwa nilai sig. $1.000>0.05$ sehingga keputusan adalah $\mathrm{H}_{0}$ diterima, dengan tingkat keyakinan 95\%, dapat diyakini bahwa model regresi logistik yang digunakan telah cukup mampu menjelaskan data/sesuai pengujian. Untuk langkah selanjutnya yaitu menggunakan uji classification plot. Uji classification plot dapat dilihat pada Tabel 4.

Tabel 5. Classification plot Untuk Variabel Waktu Tempuh Rata - rata Rute Tujuan (Surabaya - Jakarta)

Classification Table $^{\mathrm{a}}$

\begin{tabular}{|c|c|c|c|c|c|}
\hline & & & & Sredicted & \\
\hline & & & Kesediaan & h_Moda & \\
\hline & Obsened & & Tidak & lya & $\begin{array}{c}\text { Percentage } \\
\text { Correct }\end{array}$ \\
\hline Step 1 & Kesediaan_Pindah_ & Tidak & 14 & 6 & 70.0 \\
\hline & & lya & 2 & 16 & 88.9 \\
\hline & Overall Percentage & & & & 78.9 \\
\hline
\end{tabular}

Tabel 5 menunjukkan bahwa regresi logistik yang digunakan telah cukup baik karena mampu menebak dengan benar $78.9 \%$ kondisi yang terjadi.

\section{Variabel Persetujuan Terhadap Biaya KA Petikemas}

Menurut jawaban responden yang tertulis pada form survei (kuesioner) menjelaskan bahwa biaya pengangkutan barang menggunakan kereta api petikemas termasuk terjangkau atau lebih murah yaitu ukuran $20 \mathrm{ft}$. Rp. 2.500.000 dan 40 ft. Rp. 4.000.000, apabila dibandingkan dengan menggunakan truk petikemas ukuran $20 \mathrm{ft}$. Rp. 12.000.000, sedangkan ukuran 40 ft. Rp. 20.000.000, sehingga bisa digunakan sebagai alternatif pilihan pengangkutan barang. Hal ini menunjukkan adanya indikasi bahwa ada pengaruh terhadap kemungkinan atau probabilitas perpindahan moda dari truk petikemas ke kereta api petikemas, apabila biaya yang dikenakan oleh kereta api petikemas semakin murah, karena dengan biaya yang murah dapat memberikan keuntungan bagi responden.

Tabel 6. Hasil Uji Regresi Logistik Biner Untuk Variabel Persetujuan Biaya Kereta Api Rute Tujuan Surabaya -

$$
\text { Jakarta }
$$

Variables in the Equation

\begin{tabular}{|c|c|c|c|c|c|c|c|}
\hline & & $\mathrm{B}$ & S.E. & Wald & df & Sig. & $\operatorname{Exp}(B)$ \\
\hline \multirow[t]{4}{*}{ Step $1^{a}$} & Persetujuan_Biaya & & & 11.880 & 2 & .003 & \\
\hline & Persetujuan_Biaya(1) & 3.412 & .991 & 11.861 & 1 & .001 & 30.333 \\
\hline & Persetujuan_Biaya(2) & 1.872 & 1.115 & 2.817 & 1 & .093 & 6.500 \\
\hline & Constant & -1.872 & .760 & 6.073 & 1 & .014 & .154 \\
\hline
\end{tabular}

Berdasarkan Tabel 6 hasil perhitungan tersebut menunjukkan bahwa variabel persetujuan terhadap biaya kereta api petikemas rute tujuan Surabaya - Jakarta berpengaruh signifikan terhadap variabel terikat karena nilai signifikannya sig. $<\alpha$. Dimana nilai $\alpha=0.05 \%$. Yaitu $0.003 \%<0.05 \%$

\section{Persetujuan Biaya Kereta Api (1)}

Persamaan dari pemodelan hasil uji masing masing variabel bebas tersebut adalah sebagai berikut:

$$
\begin{aligned}
\operatorname{Logit}(\mathrm{p}) & =\ln \frac{p}{1-p} \\
& =-1.872+3.412 \\
& =1.54 \text { Persetujuan biaya }(1)
\end{aligned}
$$

Maka peluang responden untuk memilih kontainer ukuran $20 \mathrm{ft}$. setiap kali menggunakan kereta api petikemas apabila dikenakan biaya Rp. 2.500.000 adalah sebesar:

$$
\begin{aligned}
P(\text { Ukuran } 20 f t) & =\frac{1}{1+e^{\text {logit }}} \\
P(\text { Ukuran } 20 f t .) & =\frac{1}{1+2.718^{1.54}} \\
& =17.65 \%
\end{aligned}
$$

Sedangkan peluang responden untuk memilih kontainer ukuran $20 \mathrm{ft}$. dengan ketentuan biaya Rp. 2.500.000 apabila harus berpindah moda dari truk petikemas ke kereta api petikemas.

$$
\begin{aligned}
& P(\text { Ukuran } 20 \mathrm{ft} .)=\frac{e^{\text {logit }}}{1+e^{\text {logit }}} \\
& P(\text { Ukuran } 20 \mathrm{ft} .)=\frac{2.718^{1.54}}{1+2.718^{1.54}} \\
& =82.34 \%
\end{aligned}
$$

\section{Persetujuan Biaya Kereta Api (2)}

Persamaan dari pemodelan hasil uji masing masing variabel bebas tersebut adalah sebagai berikut:

$$
\begin{aligned}
\operatorname{Logit}(\mathrm{p}) & =\ln \frac{p}{1-p} \\
& =-1.872+1.872 \\
& =0 \% \text { Persetujuan biaya }(2)
\end{aligned}
$$

Maka peluang responden untuk memilih kontainer ukuran $40 \mathrm{ft}$. setiap kali menggunakan kereta api petikemas apabila dikenakan biaya Rp. 4.000.000 adalah sebesar:

$$
\begin{aligned}
P(\text { Ukuran } 40 f t .) & =\frac{1}{1+e^{\text {logit }}} \\
P(\text { Ukuran } 40 f t .) & =\frac{1}{1+2.718^{0}} \\
& =50 \%
\end{aligned}
$$

Sedangkan peluang responden untuk memilih kontainer ukuran $40 \mathrm{ft}$. dengan ketentuan biaya Rp. 4.000.000 apabila harus berpindah moda dari truk petikemas ke kereta api petikemas.

$$
\begin{aligned}
P(\text { Ukuran } 40 f t .) & =\frac{e^{\text {logit }}}{1+e^{\text {logit }}} \\
P(\text { Ukuran } 40 \mathrm{ft} .) & =\frac{2.718^{0}}{1+2.718^{0}} \\
& =50 \%
\end{aligned}
$$

Ringkasan probabilitas perpindahan moda dari moda truk petikemas ke moda kereta api petikemas untuk variabel persetujuan terhadap biaya kereta api petikemas dapat dilihat pada Tabel 7 .

Tabel 7. Probabilitas Perpindahan Moda Truk

Petikemas Ke Moda Kereta Api Petikemas Rute Tujuan Surabaya - Jakarta

\begin{tabular}{|l|c|c|}
\hline \multicolumn{2}{|c|}{ Persetujuan Biaya } & Probabilitas \\
\hline $\begin{array}{l}\text { Kontainer 20 ft. } \\
\text { Biaya Rp. 2.500.000 }\end{array}$ & 1.54 & $82.34 \%$ \\
\hline $\begin{array}{l}\text { Kontainer 40 ft. } \\
\text { Biaya Rp. } 4.000 .000\end{array}$ & 0 & $50 \%$ \\
\hline
\end{tabular}

Tabel 7 Menunjukkan bahwa persetujuan biaya kereta api petikemas untuk ukuran kontainer $20 \mathrm{ft}$ dengan biaya Rp. 2.500.000 lebih berpotensi terhadap probabilitas perpindahan moda dari truk petikemas ke moda kereta api petikemas mencapai $82.34 \%$. Sehingga akan lebih efisien apabila diangkut oleh kereta api petikemas dari pada diangkut oleh truk 
petikemas, karena satu rangkaian kereta api dapat memuat puluhan kontainer, berbeda dengan kapasitas daya angkut truk kontainer yang hanya dapat mengangkut satu kontainer.

Probabilitas perpindahan moda terhadap persetujuan biaya kereta api petikemas untuk ukuran kontainer $40 \mathrm{ft}$. dengan biaya Rp. 4.000.000 menunjukkan angka yang lebih kecil $50 \%$ disebabkan karena untuk ukuran kontainer $40 \mathrm{ft}$. cenderung lebih sering diangkut dengan moda truk petikemas. Meskipun demikian tetap ada kemungkinan sebesar 50 $\%$ terhadap perpindahan moda dari truk petikemas ke kereta api petikemas, karena akan lebih efisien apabila diangkut oleh kereta api petikemas dari pada diangkut oleh truk petikemas.

\section{Pengujian Model Regresi Logistik}

Sebelum model dinyatakan layak, model tersebut harus diuji statistik. Pengujian model regresi logistik biner menggunakan uji Hosmer and Lemeshow Test, dengan asumsi:

$\mathrm{H}_{0}$ : Model telah cukup mampu menjelaskan data/sesuai

$\mathrm{H}_{1}$ : Model tidak cukup mampu menjelaskan data Tolak $\mathrm{H}_{0}$ jika sig. $<0.05$

Tabel 8. Hosmer and Lemeshow Test Untuk Variabel Persetujuan Biaya Kereta Api Petikemas

Hosmer and Lemeshow Test

\begin{tabular}{|l|r|r|r|}
\hline Sten & Chi-square & df & Sig. \\
\hline 1 & .000 & 1 & 1.000 \\
\hline
\end{tabular}

Terlihat dari Tabel 8 bahwa nilai sig. $1.000>0.05$ sehingga keputusan adalah $\mathrm{H}_{0}$ diterima, dengan tingkat keyakinan 95\%, dapat diyakini bahwa model regresi logistik yang digunakan telah cukup mampu menjelaskan data/sesuai pengujian. Untuk langkah selanjutnya yaitu menggunakan uji classification plot. Uji classification plot dapat dilihat pada Tabel 9

Tabel 9. Classification plot Untuk Variabel Persetujuan Biaya Kereta Api Petikemas Rute Surabaya - Jakarta Classification Table ${ }^{\mathrm{a}}$

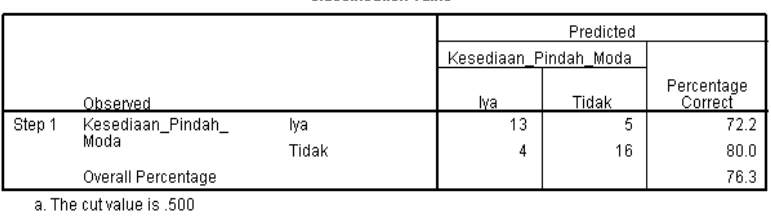

Tabel 9 menunjukkan bahwa regresi logistik yang digunakan telah cukup baik karena mampu menebak dengan benar $76.3 \%$ kondisi yang terjadi.

\section{KESIMPULAN}

Berdasarkan hasil perhitungan menggunakan analisis regresi logistik biner maka dapat diketahui nilai probabilitas pengelola jasa EMKL/Forwarder yang bersedia beralih menggunakan moda kereta api petikemas, dengan hasil analisis sebagai berikut adalah sebagai berikut:

\section{Rata - rata waktu tempuh}

Waktu tempuh selama 3 hari perjalanan menggunakan truk petikemas, akan berpotensi probabilitas perpindahan moda dari truk petikemas ke moda kereta api petikemas, dengan probabilitas perpindahan mencapai $87.49 \%$. Sedangkan probabilitas perpindahan moda pada waktu tempuh $>3$ hari menunjukkan angka yang sangat kecil yaitu 57.14 $\%$. Hal ini disebabkan karena faktor rata - rata perjalanan rute tujuan Surabaya - Jakarta bila ditempuh dengan moda truk petikemas secara umum ditempuh dalam waktu 3 hari.

\section{Persetujuan terhadap biaya kereta api petikemas}

Persetujuan biaya kereta api petikemas untuk ukuran kontainer $40 \mathrm{ft}$ dengan biaya Rp. 4.000.000 lebih berpotensi terhadap probabilitas perpindahan moda dari truk petikemas ke moda kereta api petikemas mencapai $50 \%$. Ukuran kontainer $40 \mathrm{ft}$. memiliki kapasitas yang jauh lebih besar dibandingkan dengan ukuran $20 \mathrm{ft}$. sehingga akan lebih efisien apabila diangkut oleh kereta api petikemas dari pada diangkut oleh truk petikemas, karena satu rangkaian kereta api dapat memuat puluhan kontainer, berbeda dengan kapasitas daya angkut truk kontainer yang hanya dapat mengangkut satu kontainer.

Sedangkan probabilitas perpindahan moda terhadap persetujuan biaya kereta api petikemas untuk ukuran kontainer $20 \mathrm{ft}$. dengan biaya Rp. 2.500 .000 menunjukkan angka yang lebih kecil $23.54 \%$ disebabkan karena untuk ukuran kontainer $20 \mathrm{ft}$. cenderung lebih sering diangkut dengan moda truk petikemas. khusus untuk ukuran $20 \mathrm{ft}$. ini masih dapat diangkut oleh truk petikemas dalam jumlah 2 sekaligus.

\section{DAFTAR PUSTAKA}

[1] Khisty, C, Jatin, dkk, Penerbit Erlangga Jakarta, “Dasar-Dasar Rekayasa Transportasi”, 2003 hal 9497.

[2] Siregar, Sofyian, Bumi Aksara, "Statistik Parametrik Untuk Penelitian Kuantitatif”, 2013, hal. 35-37.

[3] Informasi tentang pembangunan Jalan Flyover, dan Jalur Rel KA, di Terminal Teluk Lamong, http://www2.jawapos.com/baca/artikel/1100/pemkotsodorkan-opsi-rel-akses-teluk-lamong.

[4] Informasi tentang Terminal Teluk Lamong, http://www2.pelindo.co.id/press-release-pelindo-iiiterminal-multipurpose-teluk-lamong-beroperasi-april2014.

[5] Informasi tentang peranan Terminal Teluk Lamong, http://www.voaindonesia.com/a/terminal-teluklamong-bersiap-jadi-pelabuhan-modern-ramahlingkungan/3031901.html. 